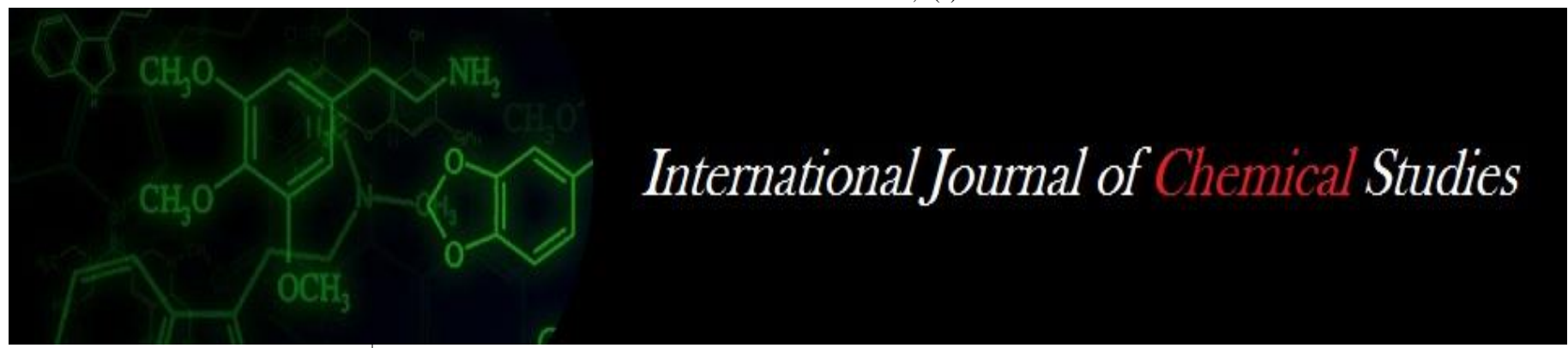

P-ISSN: 2349-8528

E-ISSN: 2321-4902

www.chemijournal.com

IJCS 2020; 8(6): 2368-2371

(C) 2020 IJCS

Received: 12-09-2020

Accepted: 20-10-2020

\section{Nidhi Nagar}

Department of Agricultural

Chemistry and Soil Science,

R.B.S College, Bichpuri, Agra,

Uttar Pradesh, India

Vipin Kumar

Department of Agricultural

Chemistry and Soil Science,

R.B.S College, Bichpuri, Agra,

Uttar Pradesh, India

\section{Raksha Pal Singh}

Swami Keshwanand Rajasthan

Agricultural University, Bikaner,

Rajasthan, India

Har Mohan Singh Yadav

Department of Agricultural

Chemistry and Soil Science,

R.B.S College, Bichpuri, Agra,

Uttar Pradesh, India

\section{Devendra Pal}

Krishi Vigyan Kendra Sambhal,

SVPUA \& T Meerut, Uttar

Pradesh, India

\section{BS Kherawat}

SMS Soil Science, KVK,

Bikaner-II, Swami Keshwanand

Rajasthan Agricultural

University, Bikaner, Rajasthan, India

Munna La

ICAR-CRIDA, Santoshnagar,

Hyderabad, Telangana, India

Corresponding Author:

Nidhi Nagar

Department of Agricultural

Chemistry and Soil Science,

R.B.S College, Bichpuri, Agra,

Uttar Pradesh, India

\section{Effect of industrial effluent discharge on physico- chemical characteristics of agricultural soil: An overview}

\author{
Nidhi Nagar, Vipin Kumar, Raksha Pal Singh, Har Mohan Singh Yadav, \\ Devendra Pal, BS Kherawat and Munna Lal
}

DOI: https://doi.org/10.22271/chemi.2020.v8.i6ah.11127

\begin{abstract}
Water is the most important natural constituent of life support system. The rapid urbanization and industrialization resulted a huge amount of polluted water which enters into the river and other water bodies causing the serious problem to environment. Due to lack of irrigation water, in the present study industrial effluent of adjoining area of Agra and Mathura used for growing crops. Effluent was containing high COD, BOD values and higher heavy metal content and the soil irrigated with this water was showing the poor status of the nutrients and high contamination of heavy metals. The present study was to evaluate the various adverse effect on the soil characteristics irrigated with effluent.
\end{abstract}

Keywords: Effluent water, heavy metal, COD, BOD

\section{Introduction}

Recent advances in science and technology since in industrial revolution increasing by enable human to exploit natural reserves. Most of Indian rivers and fresh water streams are seriously polluted by industrial waste of effluent which are produce in liquid form resulting from industrial process and domestic activity. Enviromental pollution due to increases of industrial activities are one of the most significant problem of the century. Pollution in soil and water is related to human activities such as agriculture, mining and metallurgical process and their waste disposal burning of fossil fules.

The industrial waste of industries include heavy metals copper, cadmium, lead and many other inorganic and organic toxicants and create a most serious pollution to the water and soil bodies. These may accumulate in soils in excessive quantities in long term use. However, industrial waste water could be used safely and effectively with proper precautions to increase the soil productivity. The utilization of industrial wastes for agricultural purposes could also provide a solution to the disposal problems.

Soil physicochemical properties are adversely affected by high contaminated soil unsuitable for crop production. Metals can also be transported from soil in ground water resulting in soil sickness and inhibiting growth of plants. The heavy metals accumulate in the human body through food chain directly or indirectly pose serious human and animal health. Therefore, the objective of this study deals to evaluate the Effect of industrial effluent discharge on physicchemical characteristics of agricultural soil.

\section{Material and Method}

Study area: The survey work was undertaken in the adjoining area of Agra and Mathura, Mostly the water sources for irrigation was only water canal passes via industry. The existing industry has been discharging their liquid wastes into a nearby canal.

Accordingly some of the farmers of villages are using this canal water for irrigation. By keeping this view it was thought that this activity of the industry may cause the adverse effect not only over environment but also over the farmers, the effect over farmers are in the form of health hazards as well as over the socioeconomic strara of them. 


\section{Sample collection for Effluent water}

Five water samples were collected from five sites and three to three replicate analysis was carried out for each sample. The water samples were collected in polyethylene bottles directly from the outlet of the factory linked to canal. Sampling sites were selected after each $1.0 \mathrm{~km}$ from discharging points. Four initial samples were taken from $1.0 \mathrm{~km}$ distance each, while first site was $0.1 \mathrm{~km}$ from the discharging point. Collected water samples were analyzed for physio-chemical characteristics and heavy metal content.

\section{Sample collection for soil}

Five soil sample were collected from same spots. The soil samples drawn from 0-15 and 15-30 cm depth with the help of auger. Three replicate analysis was carried out for each samples. Mainly the Sampling sites were selected approximately after each $1.0 \mathrm{~km}$ from discharging points. Four initial samples were taken from $1.0 \mathrm{~km}$ distance each, while first site was $0.1 \mathrm{~km}$ from the discharging point. The soil samples were put in plastic bags. The soil samples were air dried and kanker nodules were removed. The samples were crushed with wooden hammer and sieved through cloth. The powered samples thus obtained were stored in stoppered wide bottles with proper labeling, the samples were subjected to chemical analysis.

\section{Method of analysis for effluent water}

The $\mathrm{pH}$ of the samples was determined using the $\mathrm{pH}$ meter by calibrating the $\mathrm{pH}$ meter using the buffer solutions of known $\mathrm{pH}$ values. Electrical conductivity (EC) was determined using the conductivity meter calibrated with conductivity standard. Total suspended solids (TSS) consist of the organic as well as some of the inorganic matter which remains on the filter paper and it was determined by gravimetric method. Chlorides of the samples were determined by using argentometric method of precipitation. Chemical oxygen demand (COD) determines the oxygen Equivalent of organic matter that is susceptible to oxidation with the help of strong chemical oxidant. COD was determined by using open reflux method. Biochemical oxygen demand(BOD) is expressed as the weight of oxygen consumed per unit volume of water during defined period of time and temperature for this the sample was incubated for 5 days. For the analysis of the heavy metals $50 \mathrm{ml}$ sample was taken and $5 \mathrm{ml}$ conc $\mathrm{HNO} 3$ was added then sample were digested. The digested samples were filtered through whatman filter paper no. 42 after filtration the volume was made to $50 \mathrm{ml}$ with the deionized water. Samples were analysed on atonic absorption spectrophotometer for concentration by using specific cathode lamp. AAS was calibrated for each element using standard solution of known concentration before sample injection.

\section{Method of analysis for soil}

The $\mathrm{pH}$ of soil samples measured in 1:2.5 soil water suspension by Backman model ' $\mathrm{H}$ ' $\mathrm{pH}$ meter using glass electrode. Electrical conductivity was measured in 1:2.5 soil water suspension by method no.4, USDA Hand Book No. 60 (Richards, 1954). Organic carbon was determined by Walkely and Black's method as outlined by Jackson(1967). Rapid titration method of Piper (1966) was followed for the estimation of calcium carbonate in soil samples. Total cadmium, chromium, lead in one gm soil digested with perchloric acid (60\%) as outlined by Jackson (1967). The soil digest was filtered through whatman no.50 filter paper. Thus heavy metals in acid extract of soil were determined in an atomic absorption spectrophotometer. Available cadmium, chromium and lead analysed in the soil DTPA, 0.01M cacl2 and $0.1 \mathrm{M}$ triethanolamine $(\mathrm{pH} 7.3)$ as suggested by Lindsay and Norvell (1978). These heavy metal extract were determined in an atomic absorption spectrophotometer.

\section{Results and Discussion}

Physical Parameters: The $\mathrm{pH}$ of these samples was ranged from 7.39 to 8.20 . The $\mathrm{pH}$ values were found to highest in the site- 4 showing the alkaline nature of the water. The EC of all five samples were ranged from 2.42 to 2.91 (mmhos/cm) The conductivity values were high in the sample of site-5. Total solids of polluting material ranged between 3450 to 3900 $(\mathrm{mg} / \mathrm{l})$. The highest value of total solids were found in site-5 sample. The results are depicted in Table -1 .

Chemical Parameters: The COD values were ranged from 170 to 186 (ppm). The site- 2 was showing the highest COD value representing the high organic load in water. The BOD values of the water ranged from 280 to 390 (ppm).The highest value of BOD fond in site -5 sample. The DO values were ranged from 3.10 to $7.20(\mathrm{mmol} / \mathrm{l})$. DO values was high in site-4 sample. Chlorides was found to be in the range of 12.00-17.80 (mg/l.). Alkalinity was found to be high in the site-4 sample in summer season. It was found low in the sample collected from site-2. Sulphate values were ranged 3.40 to $5.98(\mathrm{mg} / .1)$. The highest value of sulphate found in site- 5 sample. The values of SAR and RSC 4.20 to $9.50,3.00$ to $4.00(\mathrm{mmol} / \mathrm{l})$ Highest value of SAR and RSC found in sample of site -2 and site- 3 respectively results are depicted in table 1 .

Heavy metals content of water: Heavy metal concentration was varied as cadmium,0.22-0.37 (ppm) chromium.0.25 0.50 (ppm) lead,0.80-0.92 (ppm). Heavy metals values found to be highest in site-4,site- 4 and site- 2 respectively. Results are depicted in Table-2.

\section{Soil environment}

Soil pH: Soil $\mathrm{pH}$ is a measure of the concentration of hydrogen ions in the soil. It is known to be related to the availability of nutrients for plants. Soil $\mathrm{pH}$ ranged from 8.10$8.70,8.00-8.60$ in depth $(0-15 \mathrm{~cm}),(15-30 \mathrm{~cm})$ respectively. The highest $\mathrm{pH}$ range was found in site- 4 samples in both depths.

Soil salinity: Soil salinity refers to the amount of dissolved salts in the soil solution. Effluent or combined effect of effluent and fertilizers may raise soluble salts level to the extent that they impede plant growth. However, the concentration in the soil at which salt is hazardous varies soil texture and plant species. 
Table 1: Physico-chemical properties of industrial effluents

\begin{tabular}{|c|c|c|c|c|c|c|c|c|c|c|c|c|c|c|}
\hline S. No & Location & 1 & 2 & 3 & 4 & 5 & 6 & 7 & 8 & 9 & 10 & 11 & 12 & 13 \\
\hline 1 & Site-1 & 7.98 & 2.74 & 3,750 & 576 & 105.1 & 152.50 & 14.20 & 3.80 & 182.0 & 325.25 & 4.98 & 8.23 & 3.00 \\
\hline 2 & Site-2 & 7.70 & 2.42 & 3,450 & 520 & 30.00 & 241.00 & 12.00 & 4.20 & 186.0 & 280.00 & 5.10 & 9.50 & 3.30 \\
\hline 3 & Site-3 & 7.39 & 2.82 & 3,600 & 632 & 120.00 & 274.50 & 15.70 & 3.40 & 180.5 & 340.50 & 3.80 & 5.80 & 4.00 \\
\hline 4 & Site-4 & 8.28 & 2.63 & 3,805 & 696 & 92.30 & 255.00 & 17.80 & 5.10 & 175.0 & 300.10 & 7.20 & 7.20 & 3.80 \\
\hline 5 & Site-5 & 8.05 & 2.91 & 3,900 & 710 & 70.00 & 199.20 & 13.20 & 5.98 & 170.0 & 390.00 & 3.10 & 4.20 & 3.10 \\
\hline
\end{tabular}

1. $\mathrm{pH}, 2$. EC (mmhos $/ \mathrm{cm}$ at $\left.25^{\circ} \mathrm{C}\right), 3$. Total solids $(\mathrm{mg} / \mathrm{l}), 4$. Total hardness $(\mathrm{mg} / \mathrm{l}), 5$. Carbonate $(\mathrm{mg} / \mathrm{l}), 6$. Bicarbonate $(\mathrm{mg} / \mathrm{l}), 7 \mathrm{Chloride}(\mathrm{mg} / \mathrm{l})$, 8. Sulphate (mg/l), 9. COD (ppm), 10. BOD (ppm), 11. DO (mmol/l), 12. SAR (mmol/l), 13. RSC (mmol/l)

Table 2: Concentration of heavy metals (ppm) in industrial effluent

\begin{tabular}{|c|c|c|c|c|}
\hline S. No. & Location & Cd & Cr & Pb \\
\hline 1 & Site-1 & 0.30 & 0.25 & 0.90 \\
\hline 2 & Site-2 & 0.22 & 0.38 & 0.92 \\
\hline 3 & Site-3 & 0.32 & 0.47 & 0.80 \\
\hline 4 & Site-4 & 0.37 & 0.50 & 0.83 \\
\hline 5 & Site-5 & 0.27 & 0.29 & 0.86 \\
\hline
\end{tabular}

Table 3: Physico-chemical properties of soil (0-15cm depth)

\begin{tabular}{|c|c|c|c|c|c|c|c|c|}
\hline S. No. & Location & pH & EC & CaCo3 & OC & ESP & CEC & SAR \\
\hline 1 & Site- 1 & 8.30 & 1.81 & 1.25 & 0.41 & 14.98 & 15.10 & 1.79 \\
\hline 2 & Site-2 & 8.50 & 1.14 & 2.00 & 0.55 & 14.07 & 15.60 & 1.92 \\
\hline 3 & Site-3 & 8.10 & 1.44 & 2.50 & 0.38 & 15.50 & 15.00 & 1.59 \\
\hline 4 & Site-4 & 8.70 & 1.83 & 1.00 & 0.48 & 16.00 & 15.70 & 2.04 \\
\hline 5 & Site-5 & 8.40 & 1.77 & 2.00 & 0.62 & 15.80 & 15.40 & 1.66 \\
\hline
\end{tabular}

Table 4: Physico-chemical properties of soil (15-30cm depth)

\begin{tabular}{|c|c|c|c|c|c|c|c|c|}
\hline S. No. & Location & pH & EC & CaCo3 & OC & ESP & CEC & SAR \\
\hline 1 & Site- 1 & 8.10 & 1.78 & 1.35 & 0.33 & 14.87 & 14.00 & 1.71 \\
\hline 2 & Site-2 & 8.40 & 1.11 & 2.10 & 0.41 & 14.00 & 15.50 & 1.82 \\
\hline 3 & Site-3 & 8.00 & 1.14 & 2.65 & 0.29 & 15.28 & 14.88 & 1.55 \\
\hline 4 & Site-4 & 8.60 & 1.80 & 1.15 & 0.37 & 15.92 & 15.60 & 1.99 \\
\hline 5 & Site-5 & 8.30 & 1.72 & 2.18 & 0.55 & 15.71 & 15.30 & 1.60 \\
\hline
\end{tabular}

Table 5: Concentration of heavy metals in soil ( $0-15 \mathrm{~cm}$ depth)

\begin{tabular}{|c|c|c|c|c|c|c|c|}
\hline S. No Location & Cadmium & & Chromium & & Lead & \\
\hline & & Total & Available & Total & Available Total & Available \\
\hline 1 & Site -1 & 2.80 & 0.20 & 68.00 & 0.23 & 38.00 & 1.60 \\
\hline 2 & Site -2 & 2.19 & 0.19 & 63.00 & 0.25 & 52.00 & 1.98 \\
\hline 3 & Site -3 & 2.92 & 0.27 & 66.00 & 0.19 & 41.00 & 1.32 \\
\hline 4 & Site -4 & 3.02 & 0.22 & 74.00 & 0.24 & 34.00 & 2.00 \\
\hline 5 & Site -5 & 3.00 & 0.24 & 70.00 & 0.27 & 49.00 & 2.02 \\
\hline
\end{tabular}

Table 6: Concentration of heavy metals in soil (15-30 cm depth)

\begin{tabular}{|c|c|c|c|c|c|c|c|}
\hline S. No & Location & Cadmium & & Chromium & & Lead & \\
\hline & & Total & Available & Total & Available Total & Available \\
\hline 1 & Site -1 & 2.77 & 0.18 & 69.0 & 0.21 & 36.00 & 1.58 \\
\hline 2 & Site -2 & 2.14 & 0.17 & 62.0 & 0.23 & 51.00 & 1.89 \\
\hline 3 & Site -3 & 2.87 & 0.25 & 65.2 & 0.17 & 39.50 & 1.29 \\
\hline 4 & Site -4 & 2.99 & 0.20 & 72.0 & 0.22 & 32.50 & 1.92 \\
\hline 5 & Site -5 & 2.97 & 0.21 & 68.0 & 0.25 & 47.00 & 1.98 \\
\hline
\end{tabular}

Soil conductivity: The conductivity of soil samples was ranged $1.14-1.83,1.11-1.80$ (mmhos/cm at $25^{\circ} \mathrm{C}$ ) in depth $(0-15 \mathrm{~cm}),(15-30 \mathrm{~cm})$ respectively. The range was highest in the sample of site- 4 in both depths.

Organic carbon: Organic carbon content in these soil depth $(0-15$ and $15-30 \mathrm{~cm})$ ranged from $0.38-0.62$ and $0.29-0.55 \%$. Highest range found site- 5 samples in both depths.

Soil Exchangeable sodium percentage (ESP) and Cation exchange capacity (CEC): The ESP of soil samples were found 14.07-16.00 and 14.00-15.92 in depth (0-15 cm), (15-30 $\mathrm{cm})$ respectively. CEC ranged 15.00-15.70 and 14.00-15.60. The highest values found site-4 soil sample.
Sodium absorption ratio (SAR): Sodium absorption ratio was ranged 1.59-2.04 and 1.55-1.99 (mmol/l) in depth $(0-15$ $\mathrm{cm}),(15-30 \mathrm{~cm})$ respectively. Highest results of SAR found in site -4 sample. Results are depicted in table-3nd table-4.

From the results it is clear that the soil category comes under the poor quality of the soil.

Heavy metals: Number of heavy metals present in the industrial effluent were being leached in soil by diverting effluents for irrigation purpose. The concentration of heavy metals were in the range of total and available cadmium 2.19 $3.02,2.14-2.97,0.19-0.27,0.17-0.25$ total and available chromium $63.00-74.00,62.5-72.00,0.19-0.27,0.17-$ 0.25 , total and available lead $34.00-52.00,32.50-47.00$, $1.32-2.02,1.29-1.98(\mathrm{ppm})$ in depth $(0-15 \mathrm{~cm}),(15-30 \mathrm{~cm})$ respectively. Results are depicted in table- 5 and table- 6 .

\section{Discussion}

As it was already mentioned every manufactured product uses water during some part of the production process. The water discharged during the manufacturing process of the above mentioned industry may cause the adverse effects over environment. In the same manner color odor also changes. When the Physio-chemical parameters are taken into consideration, the physical parameters shows that $\mathrm{pH}$, TS are more while the total hardness is far more as compare to the normal value. The high COD value from the effluents of the industry suggests that this industry is producing lots of organic substances BOD value of this industry also shows very high results.

The heavy metals present in the effluent may come from the various metallurgical processes. The data suggest that near about concentration of all the metals goes on decreasing which indicate that the effluent may contains metal quenchers thus the trace elements required by the plants are not properly supplied which results the underproduction of the crops in a particular area. The fertility status of the soil was also tested and suggested that the fertility level of the surrounding fields are into very poor category. The above data also suggest that the effluent discharge point cause comparatively deleterious effect over the surrounding environment.

\section{Conclusion}

The industries concentrated mainly on the bank of various rivers in our country, receive huge amount of industrial waste water. These industrial effluents are characterized by high BOD and COD levels and contain high percentage of different organic and inorganic materials, depending upon the sources of their origin.

Thus the present work concludes that the effluent from the industry causes the pollution in surrounding environment. The status of the samples showed that the soil quality of the surrounding field was poor and the effluent discharged in canal has been affecting the physicochemical characteristics of soil. The heavy metals in the field were also showing the 
high concentration which also causes the adverse effect on the soil. Through this study, it is concluded that the industrial effluent has substantially changed the irrigation water quality and consequently some chemical elements also increased in the soil of irrigated farmland.

It is imperative that industrial waste water should not be allowed to be discharged on land outside the framework of widely tested agronomic package.

\section{References}

1. Antil RS, Narwal RP. Influence of sewer water and industrial effluents on soil and plant health. In Groundwater resources: Conservation and management, V.D. Puranik, V.K. Garg, A. Kaushik, C.P. Kaushik, S.K. Sahu, A.G. Hegde, T.V. Ramachandan. I.V. Saradhi \& P. Prathibha (Ed.), 37-46, Department of Enviromental Science and Engineering, GJU Science and Technology Hisar, India 2008.

2. APHA. Standard methods for the examination of water and waste water. American Public Health Association, Washington D.C.(21 $1^{\text {st }}$ edn $) 2005$.

3. Azad AS, Arora BR, Singh B, Sekhon GS. Nature and extent of heavy metal pollution from industrial units in Ludhiana. Indian J Ecol 1984;2(1):1-5.

4. Baruah BK, Baruah D, Das M. Study on the effect of paper mill effluent on the water quality of receiving wetland. Poll. Res 1996;15(4):389-393.

5. Baskaran L, Sankar Ganesh K, Chidambaram ALA, Sundaramoorthy P. Amelioration of Sugar Mill effluent Polluted Soil and its Effect on Green gram(Vigna radiate L.,), Botany Research International 2009;2(2):131-135.

6. Chatterjee A, et al. Impact of distillery and paper mill effluent irrigation on yield of rice and soil fertility.J. Indian Soc. Soil Sci 2003;51(4):564-566.

7. FAO. Terminal report of project TCP BAR 2303 Use of marginal quality of irrigation. FAO, Rome 1985.

8. Fytianos K, Kastsiani G, Triantafyllou P, Zachariadis G. Accumulation of heavy metals in vegetables grown in an industrial area in relations to soil. Bull. Environ. Contam. Toxicol 2001;67:423-430.

9. Jackson ML. Soil Chemical Analysis. Prentice Hall of India Pvt. Ltd. New Delhi 1973.

10. Narsimharao P, Narsimharao Y. Quality of effluent water discharged from paperboard industry and its effect on alluvial soil and crops. Indian J Agric Sci 1992;62(1):912 .

11. Nemade PN, Shrivastava VS. Detection of metals in pulp and paper mill effluent by ICP-ACE and flemphotometry and their impact on surrounding environment. J Indust. Poll. Cont 1997;13(2):143-149.

12. Sharma RK, Agrawal M, Marshall FM. Heavy metal $(\mathrm{Cu}, \mathrm{Zn}, \mathrm{Cd}$, and $\mathrm{Pb})$ contamination of vegetables in Urban India: a case study at Varanasi, Environ. Pollution 2008; 154:254-263.

13. Singh AP, Satya Prakash, Sakal R. Adsorption behavior of chromium in soil after long time treatment with sewage sludge. J. Indian Soc. Soil Sci 1998;46(4):592599.

14. Singh HP, Mahaver LR, Mishra JP. Impact of Industrial and sewage wastes on water qualities in middles stretch of river Ganga from Kanpur to Varanasi J.of Environ. Biology 1999;20(3):279-285.

15. Wong JWC, Lai KM, Su DS, Rang M. Availability of heavy metals for Brassica chinensis grown in an acidic loamy soil amended with domestic and industrial sewage sludge. Water Air and Soil Pollution 2001;128:339-353. 